\title{
Islamic Education Teachers' Efforts in Developing Students' Spiritual Potencial in Learning (A Study at SMP N 29 Padang)
}

\section{Silvia Susrizal*)}

Institut Agama Islam Negeri Batusangkar, Sumatera Barat, Indonesia

E-mail: susrizalsilvia@yahoo.co.id
Abstract: This study was conducted because of the need to develop students' spiritual potential in the learning process conducted by teachers of Islamic Education at SMP N 29 Padang. The purpose of this study is to determine the efforts undertaken by teachers of Islamic Religious Education to develop the spiritual potential of students in improving the learning process.In this research, teacher effort in developing potencial student has not been maximal yet. Aamong the indication is that students have not showed their religious attitude to students either through attitude, behavior, speech or association because the learning model created in the learning process has not given opportunity for students to do so. So that the learning has not given meaning to the students themselves which resulted the ungrowth of the students' awareness.

Key words: Islamic education teachers, potential, spiritual, learning process

\section{PENDAHULUAN}

Manusia dilahirkan ke atas dunia ini telah dibekali dengan potensi yang akan membuatnya hidup bahagia dan berhasil. Manusia dengan potensi yang dimilikinya ini menjadi unsur terpenting dalam menentukan keberhasilannya.Karena pada dasarnya semua manusia mempunyai potensi sama, akan tetapi potensi itu ada yang digali dan ditumbuh suburkan menjadi potensi yang luar biasa, di sisi lain ada yang tidak mengembangkan potensinya dengan maksimal, karena potensi-potensi akan berkembang sesuai dengan faktor-faktor yang mendukungnya.

Dalam al-Qur'an potensi yang dimiliki manusia diistilahkan dengan fitrah. Potensi yang dimiliki manusia pada hakikatnya merupakan kemampuan dasar manusia yang meliputi kemampuan mempertahankan kelestarian kehidupannya, kemampuan rasional maupun kemampuan spiritual (Samsul Nizar, 2001 : 209). Dalam surat Ar-rum ayat 30 Allah menjelaskan :

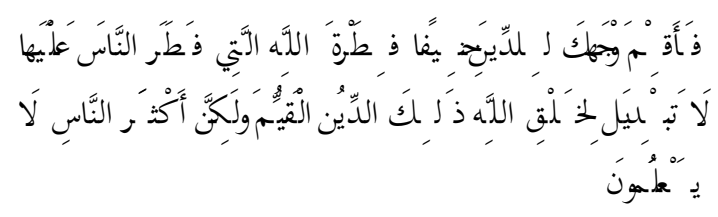

Terjemahannya: Maka hadapkanlah wajahmu dengan lurus kepada agama (Allah); (tetaplah atas) fitrah Allah yang telah menciptakan manusia menurut fitrah itu. Tidak ada perubahan pada fitrah Allah. (Itulah) agama yang lurus; tetapi kebanyakan manusia tidak mengetahui.

Begitu juga menurut hadits yang diriwayatkan oleh Imam Bukhari, sebagai berikut:

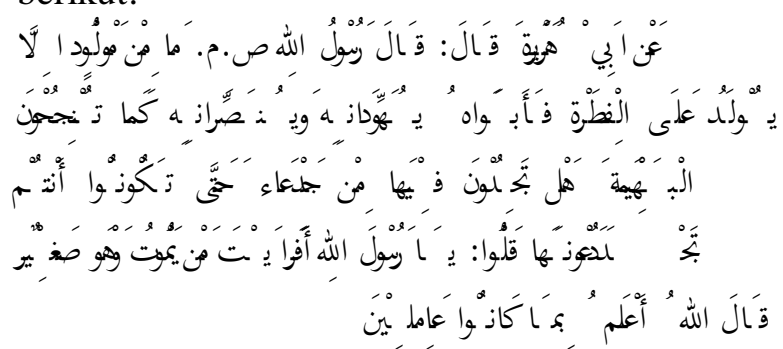

Terjemahannya: Dari Abu

Hurairah r.a Katanya : Rasulullah saw bersabda:"Setiap anak dilahirkan menurut fitrah (ciptaan asli). Kedua ibu bapanya yang menyebabkan anak itu beragama 
Yahudi dan Nasrani. Sebagaimana binatang ternak dilahirkan, adakah kamu dapati yang telah dipotong (dilobangi) hidungnya sehingga kamu tidak perlu lagi memotongnya?". Mereka bertanya lagi :"Ya Rasulullah! bagaimana pendapat engkau tentang anak yang meninggal di waktu kecil ?" Jawab Nabi: "Allah lebih mengetahui apa yang mereka kerjakan.”

Ayat di atas mempunyai makna (Tafsir jalalain) cenderungkanlah dirimu kepada agama Allah, yaitu dengan cara mengikhlaskan dirimu dan orang-orang yang mengikutimu di dalam menjalankan agama-Nya (fitrah Allah) ciptaan-Nya (yang telah menciptakan manusia menurut fitrah itu) yakni agama-Nya. Makna yang dimaksud ialah, tetaplah atas fitrah atau agama Allah. (Tidak ada perubahan pada fitrah Allah) pada agama-Nya. Maksudnya janganlah kalian menggantinya, misalnya menyekutukan-Nya. (Itulah agama yang lurus) agama tauhid itulah agama yang lurus (tetapi kebanyakan manusia) yakni orang-orang kafir Mekah (tidak mengetahui) ketauhidan atau keesaan Allah.

Potensi dasar ini akan menjadikan manusia makhluk yang berbeda dengan makhluk lainnya, mampu menjadi khalifah Fil Ardh, hamba yang taat, menjadi manusia inovatif, kreatif, konstruktif, dan menjadi manusia yang paripurna (Insan Kamil). Diantara potensi dasar itu adalah potensi spiritual. Potensispiritual ini sangat penting karena merupakankemampuan menghidupkan kebenaran yang paling dalam yang berarti mewujudkan kebenaran yang terbaik, utuh, dan paling manusiawi dalam batin. Potensi spiritual ini dipopulerkan oleh Danah Zohar dan Ian Marshall, menurut mereka manusia yang memiliki potensi spiritual "god spot" yang tinggi hidupnya akan mampumenghadapi persoalan makna yang lebih luas (Ramayulis,2002:106). Potensi ini sebenarnya sudah tergambar dalam pendapat ulama abad pertengahan yaitu Ibnu Taimiyah, bahwa pada diri manusia juga memiliki diantaranya Daya defensif
(Quwwat Al-Ghadhab) yaitu potensi dasar yang dapat menghindarkan manusia dari segala perbuatan yang membahayakan dirinya (Samsul Nizar,2001:76).

Potensi yang diberikan Allah ini seperti yang telah dijelaskan sebelumnya akan menjadi potensi luar biasa jika dikembangkan, karena itu upaya efektif untuk mengembangkan potensi ini adalah melalui upaya pendidikan, maka pelaku pendidikan mengarah dan menyatu menuju usaha pengembangan ini, diantaranya adalah guru. Dalam Pendidikan Islam guru bertanggung jawab mengantarkan manusia ke arah terciptanya Insan Kamil.

Justru itu keberadaan pendidik dalam dunia pendidikan sangat krusial, sebab kewajibannya tak hanya mentransformasikan pengetahuan tetapi juga dituntut menginternalisasikan nilainilai pada peserta didik (Ramayulis,2002:55) melalui metode, media, materi, alat, dan kurikulum yang dirancang oleh pendidik diusahakan agar menyentuh ranah spiritual peserta didik.

Sekolah Menengah Pertama Negeri (SMPN) 29 Padang sebagai salah satu lembaga pendidikan yang merupakan wadah melahirkan generasi-generasi berkualitas juga berupaya untuk mengembangkan potensi spiritual siswa baik dalam proses pembelajaran di kelas maupun kegiatan non pembelajaran denganbaik sesuai dengan ilmu didaktikdan hakikat pengembangan potensi itu sendiri. Sebenarnya ada hubungan timbal balik antara usaha guru pendidikan Agama Islam dalam pengembangan potensi dengan proses pembelajaran. Jika usaha pengembangan potensi maksimal maka akan berdampak positif terhadap proses pembelajaran, dan begitu juga sebaliknya jika pelaksanaan proses pembelajaran yang terjadi efektif maka potensi akan bisa dikembangkan dengan baik. 
Potensi Spiritual

Pengertian Potensi Spiritual

Kecerdasan spiritual adalah kecerdasan untuk menghadapi persoalan makna atau value, yakni kecerdasan untuk menempatkan perilaku dan hidup dalam konteks makna yang lebih luas (Husnaini A, Artikel Keseimbangan IQ, EQ, SQ dalam Perspektif Islam,h.5). Dr. Marsha Sinetar seperti yang disitir oleh Sukidi memberikan defenisi spiritual ini sebagai pemikiran yang terilhami (Sukidi,2002:49).Kecerdasan spiritual adalah kemampuan untuk memberi makna ibadah terhadap setiap perilaku dan kegiatan, melalui langkah-langkah dan pemikiran yang bersifat fitrah, menuju manusia yang seutuhnya (hanif), dan memiliki pola pemikiran pola tauhidi (integralistik), serta berprinsip "hanya karena Allah"(Ary Ginanjar Agustin,2001:57).

Dalam al-Qur'an kecerdasan spiritual mengacu pada kecerdasan Illahi, jiwa yang menurut terminologi alqur'an disebut dengan qalbu (Sukidi,2002:62).Alqur'an sendiri menunjukkan istilah-istilah semakna dengan kata qalbu tetapi memiliki fungsi yang berbeda, antara lain : Fuad, lubb, shadr, syaghaf, roh, dan nafs.

\section{Ciri-ciri Potensi Spiritual}

Tanda-tanda kecerdasan spiritual ditandai oleh kemampuan bersikap fleksibilitas, tingkat kesadaran diri yang tinggi, kemampuan memanfaatkan penderitaan, kemampuan melawan rasa sakit, kualitas hidup yang diilhami oleh visi dan nilai-nilai keengganan menyebabkan kerugian yang tidak perlu, kemampuan melihat keterkaitan segala hal, selalu bertanya mengapa? Atau bagaimana untukmencari jawaban yang mendasar dan kemandirian dalam berpikir.

Ada 6 alasan kecerdasan spiritual lebih penting dari kecerdasan intelektual dan emosional (Sukidi,2002:68-78) : (1) Segi perenial SQ Kecerdasan spiritual mampu mengungkap segi perenial (yang abadi, yang asasi, yang spiritual, yang fitrah) dalam struktur kecerdasan manusia. (2) Mind-body-soul. Kecerdasan spiritual menjadi lokus kecerdasan yang berfungsi tidak saja sebagai pusat kecerdasan melainkan juga berfungsi dalam memfasilitasi antara otak dan emosi. (3) Kesehatan spiritual. Dewasa ini terjadi penyakit jiwa spiritul yang lebih banyak diderita manusia modern., yang jawaban tidak dapat kita peroleh dari IQ dan EQ. Kecerdasan spiritual bukan saja menyentuh segi spiritual melainkan juga menyajikan beragam resep mulai dari pengalaman spiritual sampai penyembuhan spiritual, sehingga kita benar-benar mengalami segi kesehatan spiritual. (4).Kedamaian spiritual. Kecerdasan spiritual membimbing kita meraih kedamaian hidup secara spiritual. (5). Kebahagiaan spiritual. Kebahagiaan sejati terletak pada kebahagiaan spiritual; suatu kebahagian yang membuat hati dan jiwa menjadi bahagia, tentram, dan penuh kedamaian. (6).Kearifan spiritual. Setelah meraih kebahagiaan spiritual, kecerdasan spiritual mengarahkan kita kepuncak tangga, yakni kearifan spiritual, baik IQ maupun EQ justru cendrung pada arogansi intelektual, rakus material, dan perbudakan emosional. Padahal kearifan apalagi kearifan spiritualmengatasi dan bahkan melampaui itu semua dengan menekankan segi-segi kearifan spiritual dalam menjalani hidup di dunia yang serba material dan sekuler ini. Kearifan spiritual, memang menuntun dan menjadikan kita arif dan bijak dalam kehidupan sehari-hari. Tidak mudah memang bisa bersikap arif dan bijak, karena ini merupakan hikmah kearifan tertinggi dalam hidup kita.

\section{Peranan Pendidik dalam Mengembangkan Potensi Spiritual Siswa}

Pendidikan spiritualitas yang dapat menajamkan kualitas kecerdasan spiritual, baik terhadap diri sendiri sebagai pendidik maupun sebagai siswa, adalah nilai-nilai 
spiritual itu sendiri yang diinternalisasikan ke dalam pendidikan kita. Nilai-nilai yang dimaksud adalah kejujuran, keadilan, kebajikan, kebersamaan, kesetiakawanan sosial, dan sebagainya. Nilai-nilai itu harus diinternalisasikan dalam diri siswa sejak usia dini. Sebagai pendidik yang juga ingin meraih kualitas kecerdasan spiritual yang tinggi, kita bisa memperoleh kecerdasan spiritual itu melalui sikap keteladanan dalam mengajarkan pendidikan spirirtualitas (Sukidi, 2002:68).

Sebagai contoh pendidikan akan arti pentingnya sebuah kejujuran misalnya, dapat diinternalisasikan dalam diri siswa melalui keteladan moral pendidik itu sendiri, karena faktor keteladanan moral seorang pendidik ini sangat menentukan psikologi dan kepribadian siswa. Nilainilai seperti kejujuran dan keteladanan moral yang baik itulah yang menjadi level tertinggi kecerdasan spiritual kita ( Sukidi,2002:89).

Adapun dimensi-dimensi spiritual yang dapat dikembangkan oleh pendidik, adalah sebagai berikut (Yusuf Al qaradhawi,2004:93-95): Keimanan kepada Allah ta'ala; keimanan kepada akhirat, tempat pembalasan dan keabadian yang mana setiap jiwa diberikan balasan atas segala sesuatu yang dilakukannya; peribadatan kepada Allah dan ketaqwaan kepadaNya, dengan melaksanakan seluruh kewajiban-kewajiban dan menegakkan syiar-syiarNya, menaati perintahNya, dan menjauhi larangannya; pendekatan diri kepada Allah, dengan cara mengerjakan hal-hal sunnah, dzikir, tasbih, tahmid, tahlil, takbir, do'a, dan istighfar; pembersihan hati dari penyakit-penyakit mental dan moeral serta penyakit-penyakit hati; pendekatan diri kepada Allah dengan cara mengerjakan kebaikan-kebaikan, perbaikan kepada manusia, kasih sayang kepada segenap makhlukNya, mendukung perbuatan makruf, menolong yang membutuhkan, melapangkan orang yang sedih, dan menghapus air mata orang yang menderita.
Untuk melaksanakan peranan guru pendidikan Agama Islam mengembangkan potensi ini, salah satu strategi yang baik digunakan guru adalah strategi PAIKEM.

Sudijarto (Abimanyu, 2008 : 2-3) mendefinisikan strategi sebagai upaya memilih, menyusun,dan memobilisasi segala cara, sarana/prasarana, dan tenaga untuk menciptakan sistem lingkungan untuk mencapai perubahan perilaku optimal. Jadi, strategi merupakan pemilihan upaya yang akan memberi peluang tercapainya tujuan yang optimal, baik dari segi hasil belajar, hasil kerja, maupun proses belajar.

Terdapat beberapa kriteria yang bisa digunakan sebagai acuan dalam pemilihan strategi, yaitu:

1. Relevansi

Derajat kaitan fungsional antara strategi sebagai dimensi instrumental dengan tujuan/sasaran belajar, dengan tolok ukur dari sebagaimana sesuatu itu dipelajarai dan bukannya dari segi apa yang dipelajari. Derajat relevansi dapat ditinjau dari tiga dimensi yaitu epistemologi, psikologi, dan sosial.

2. Efektivitas

Efektivitas (hasil guna) yakni tingkat instrumentalitas atau hubungan kausal linier antara strategi dengan tujuan yang ingin dicapai. Muara keberhasilan dapat diukur dari segi efektivitas, baik dari segi dampak instruksional maupun dampak pengiring.

3. Efisiensi

Efisiensi (daya guna) yakni berkaitan dengan perbandingan upaya (proses belajar) dengan hasil (pencapaian tujuan) khususnya ditinjau dari prinsip ekonomis, seperti pemilihan strategi yang lebih sederhana, murah dan mudah serta bervariasi tetapi mencapai tujuan yang optimal.

PAIKEM sebagai suatu pendekatan telah memuat di dalamnya kriteria utama dalam mengembangkan strategi . Secara garis besar, kelima kriteria dalam 
PAIKEM adalah aktif, inovatif, kreatif, efekif, dan menyenangkan.

Berbagai macam model PAIKEM yang dapat dijabarkan sebagai berikut: Pertama, kooperatif menurut Slavin (Kemp,1994:151) adalah tipe khusus dari aktivitas kelompok yang mengupayakan untuk mengembangkan antara kemampuan belajar dan kemampuan sosial dengan memasukan tiga konsep/komponen ke dalam yaitu penghargaan kelompok, tanggung jawab individu, dan kesempatan yang sama untuk sukses. Pertimbangan dari komponen-komponen tersebut menunjukkan bahwa kooperatif membutuhkan perencanaan yang hati-hati dan pelaksanaan yang sistematis. Ini lebih dari menugaskan siswa untuk berkelompok dan menyuruh mereka untuk saling mengajari satu sama lain atau menyelesaikan tugas.

Kedua, kontekstual adalah yang diawali dengan sajian atau tanya jawab lisan yang ramah dan terbuka terkait dengan kehidupan sehari-hari siswa, sehingga dapat mengetahui manfaat dari materi yang akan disajikan, motivasi belajar pada diri siswa akan muncul, dunia pikiran siswa menjadi konkret, serta suasana menjadi kondusif, nyaman dan menyenangkan. Prinsip kontekstual adalah aktivitas siswa, siswa melakukan dan mengalami tidak hanya menonton dan mencatat, serta pengembangan kemampuan sosialisasi (Rosalin ,2008:112). Depdiknas (Masyhud, 2012:51) menyatakan bahwa kontekstual harus melibatkan tujuh komponen utama efektif, yaitu: (1) Construktivism (membangun), (2) Inquiry (menemukan), (3) Questioning (bertanya), (4) Learning Community (masyarakat belajar), (5) Modeling (pemodelan), (6) Reflection (refleksi), (7) Authentic Assessment (penilaian autentik).

Ketiga, Model Problem Based Learning (PBL) adalah yang memungkinkan siswa untuk secara aktif terlibat dalam pengalaman belajarnya dan dapat melatih keteranpilan berfikir siswa (penalaran, komunikasi, dan koneksi) dalam memecahkan masalah (Rusman,2012:229). Model Problem Based Learning (PBL) mempunyai ciri umum yaitu menyajikan kepada siswa tentang masalah yang autentik dan bermakna yang akan memberi kemudahan kepada para siswa untuk melakukan penyelidikan dan inkuiri. Menurut Arends model ini juga memiliki beberapa ciri khusus yaitu adanya pengajuan pertanyaan atau masalah, berfokus pada keterkaitan antar disiplin ilmu, penyelidikan autentik, menghasilkan produk atau karya, dan memamerkan produk tersebut, serta adanya kerja sama (Suryanti,2008:20).

Keempat, Berbasis proyek menurut The George Lucas Educational Foundation (http://journal.unnes.ac.id) adalah model yang menuntut pengajar dan atau peserta didik mengembangkan pertanyaan penuntun (a guiding question). Mengingat bahwa masing-masing peserta didik memiliki gaya belajar yang berbeda, maka berbasis proyek memberikan kesempatan kepada para peserta didik untuk menggali konten (materi) dengan menggunakan berbagai cara yang bermakna bagi dirinya, dan melakukan eksperimen secara kolaboratif. Hal ini memungkinkan setiap peserta didik pada akhirnya mampu menjawab pertanyaan penuntun.

Kelima, model kuantum adalah model dengan enam kerangka (TANDUR) serta memperhatikan lingkungan belajar siswa dan dibutuhkan peran serta guru sebagai quantum teacher untuk mendayagunakan kemampuannya, mengorkestrasi dalam kegiatan pembelajaran. kuantum memiliki lima prinsip atau kebenaran tetap. Prinsipprinsip tersebut adalah: (1) segalanya berbicara, (2) segalanya bertujuan, (3) pengalaman sebelum pemberian nama, (4) akui setiap usaha, (e) jika layak dipelajari, layak pula dirayakan (Chatib, 2010:35). Model Quantum Teaching and Learning terdapat unsur-unsur peristiwa yang 
dibagi menjadi dua katagori yaitu konteks dan isi.

\section{METODE PENELITIAN}

Jenis penelitian yang penulis gunakan adalah penelitian kualitatif yang bersifat deskriptif (Hadari Nawawi,1996:23). Dengan pendekatan ini dihasilkan data deskripsi baik dalam bentuk kata-kata tertulis, kata-kata lisan atau perilaku manusia yang diamati (Sutrisno Hadi,1987:136). Peristiwa atau kejadian yang dimaksud dalam penelitian ini berkaitan dengan usaha-usaha guru Pendidikan Agama Islam mengembangkan potensi spiritualsiswa dalam meningkatkan proses pembelajaran di SMP N 29 Padang. Tahapan kerja yang dilakukan adalah pengumpulan data, analisis data, dan penarikan kesimpulan.

Sumber data primer dalam penelitian ini adalah guru pendidikan Agama Islam Sekolah Menengah Pertama Negeri (SMP $\mathrm{N}$ 29) Padang yang jumlah gurunya 3 orang, seperti dalam tabel berikut:

\begin{tabular}{|l|l|l|}
\hline No & Nama Guru & Kelas Mengajar \\
\hline 1 & Mahlab Sufrah, BA & Kelas VII \\
\hline 2 & Drs. Yuliusman & Kelas VIII \\
\hline 3 & Hj. Elinur, S.Pd.I & Kelas IX \\
\hline
\end{tabular}

Sumber Data diperoleh dari Waka Kurikulum

Sumber data sekunder tersebut adalah wakil kepala bidang kurikulum SMP N 29 Padang.

Untuk memperoleh data yang akurat serta dapat dipertanggungjawabkan, maka dalam penelitian ini penulis menggunakan instrumen pengumpulan data sesuai dengan informasi yang dibutuhkan dalam penelitian ini, yaitu observasi, wawancara, dan dokumentasi. Kemudian data dianalisis dengan proses menyusun atau mengolah data agar dapat ditafsirkan lebih lanjut. Data yang telah diperoleh dari hasil observasi dan wawancara dianalisis untuk diketahui maknanya. Hal ini dilakukan dengan menyusun dan menghubungkan data-data, mereduksi data, dan menarik kesimpulan atau verifikasi. Proses ini dilakukan selama dan sesudah pengumpulan data dan berlangsung secara sirkuler.

\section{HASIL PENELITIAN}

Potensi spiritual ini memberikan pengaruh yang luar biasa, yang menyinari perkembangan potensi intelektual dan emosional, yang memberikan ruh Ilahiyah pada keduanya, yang menentukan seseorang itu baik atau tidak, berhasil atau tidak.

Dalam proses pembelajaran,
seorang guru berperan untuk mengembangkan potensi ini, melalui materi atau interaksi yang dilakukannya dengan siswanya, seperti pada pengembangan potensi emosional siswa. Akibat yang bisa kita jadikan cerminan seorang siswa yang tidak berkembang potensi spiritualnya adalah tindakan kecurangan dalam setiap ujian, apalagi pada ujian Nasional; manipulasi nilai; siswa yang berakhlak bobrok, dan keburukan-keburukan akhlak lainnya.

1. Kemampuan tekun menghadapi tugas (dapat bekerja terus menerus dalam waktu yang lama, tidak berhenti sebelum selesai) karena Allah. Belum ada penulis rasakan dalam proses pembelajaran. Sebagai contoh, siswa masih asal-asalan dalam menghadapi tugas, dalam diri mereka yang terpikir hanya bermain game online, facebook, jejaring sosial lainnya, sms pacar, dan segala yang melalaikan para siswa. Padahal untuk mengerjakan tugas yang diberikan oleh guru, siswa harus mampu bersikap tekun dan ulet.

Penulis melihat guru agama Islam belum mampu dengan baik memotivasi siswa mereka agar mau mengerjakan tugas yang guru berikan kepada mereka dengan benar. Selain terkendala dengan diri siswa sendiri, guru juga masih belum termotivasi untuk mendorong siswa-siswa mereka agar semangat dalam belajar.

2. Kemampuan ulet menghadapi kesulitan (tidak lekas putus asa)/ istiqomah Kemampuan ini masih dirasa hambar 
dalam proses pembelajaran, apalagi dengan segala faktor negatif yang ada pada diri siswa dan guru akan sulit untuk memiliki kemampuan ulet ini ini maunya yang praktis saja tapi berhasil. Misal, dalam mengerjakan LKS atau tugas lainnya siswa menjawabnya sembarangandan mencontek dengan temannya.

3. Kemampuan tidak memerlukan dorongan dari luar untuk berprestasi. Usia ini umumnya sangat memerlukan dorongan dari luar karena sedang berada dalam masa mencari jati diri termasuk perhatian dan dorongan dari orang lain. Apalagi kondisinya seperti yang terjadi di SMP 29 Padang ini, siswa memiliki motivasi diri yang rendah.

4. Kemampuan ingin mendalami bahan/bidang pengetahuan yang diberikan, belum nampak oleh peneliti.

5. Kemampuan selalu berusaha berprestasi sebaik mungkin (tidak cepat puas dengan prestasinya). Penjelasan dari wakil kepala bidang kurikulum belum ada prestasi dalam bidang keagamaan. Jangankan siswanya yang berprestasi, gurunya saja belum mempunyai prestasi dalam mengajar.

6. Minat terhadap macam-macam masalah "orang dewasa" (misalnya terhadap pembangunan, korupsi, keadilan dan sebagainya)/mempunyai kepedulian. Penulis belum melihat pengembangan ini dalam proses pembelajaran di kelas VII dan kelas VIII.

7. Kemampuan senang dan rajin belajar, penuh semangat, tidak cepat bosan dengan tugas-tugas rutin, dapat mempertahankan pendapat-pendapatnya (kalau sudah yakin akan sesuatu, tidak mudah melepaskan hal yang diyakini tersebut). Penulis belum melihat pengembangan ini dalam proses pembelajaran di kelas VII dan kelas VIII

8. Kemampuan mengejar tujuan-tujuan jangka panjang (dapat menunda pemuasan kebutuhan sesaat yang ingin dicapai kemudian)/cinta akhir. Penulis belum melihat pengembangan ini dalam proses pembelajaran di kelas VII dan kelas VIII.

9. Kemampuan senang mencari dan memecahkan soal-soal. Penulis belum melihat pengembangan ini dalam proses pembelajaran di kelas VII dan kelas VIII.

Dari uraian di atas, untuk pengembangan potensi spiritual dalam proses pembelajaran masih dirasakan kehambarannya. Guru PAI lebih mendominasikan pada pengembangan potensi intelektual dan belum berusaha pada pengembangan potensi emosional, dan potensi spiritual. Guru belum berupaya penuh mengajarkan siswa agar mampu mengambil makna dari proses pembelajaran yang dijalaninya. Kita tahu siswa pada usia remaja ini sedang mencari jati dirinya, jadi mereka akan melakukan tindakan imitasi dan identifikasi pada orang-orang yang dianggapnya sesuai dengan keinginan atau karakter dirinya yang belum jelas ini. Maka sangat besar sekali pengaruh guru terhadap perkembangan potensi spiritual siswanya. Selama di lapangan penulis melihat sikap guru agama Islam yang belum menampakkan sikap keberagamaannya kepada siswa, baik melalui sikap, tingkah laku,ucapan, atau pergaulan.

Siswa-siswa belum mempunyai kemampuan untuk melakukan semua hal ini karena model pembelajaran yang tercipta dalam proses pembelajaran belum memberikan kesempatan untuk siswa untuk melakukannya, sehingga pembelajaran belum memberikan makna terhadap diri siswa yang berakibat kepada belum tumbuhnya kesadaran dalam diri siswa untuk berprestasi lebih baik.

\section{PENUTUP}

Kesimpulan

Usaha guru Pendidikan Agama Islam dalam mengembangkan potensi spiritual siswa adalah: kemampuan tekun menghadapi tugas (dapat bekerja terus 
menerus dalam waktu yang lama, tidak berhenti sebelum selesai) karena Allah ; kemampuan ulet menghadapi kesulitan (tidak lekas putus asa)/ istiqomah ; kemampuan tidak memerlukan dorongan dari luar untuk berprestasi ; kemampuan ingin mendalami bahan/bidang pengetahuan yang diberikan; kemampuan selalu berusaha berprestasi sebaik mungkin (tidak cepat puas dengan prestasinya) ; minat terhadap macam-macam masalah "orang dewasa" (misalnya terhadap pembangunan, korupsi, keadilan dan sebagainya) /mempunyai kepedulian ; kemampuan senang dan rajin belajar, penuh semangat, tidak cepat bosan dengan tugas-tugas rutin, dapat mempertahankan pendapat-pendapatnya (kalau sudah yakin akan sesuatu, tidak mudah melepaskan hal yang diyakini tersebut) ; kemampuan mengejar tujuan-tujuan jangka panjang (dapat menunda pemuasan kebutuhan sesaat yang ingin dicapai kemudian)/cinta akhirat ; kemampuan senang mencari dan memecahkan soal-soal

Saran

Kepada guru PAI di SMP N 29 Padang sebaiknya terus mengembangkan kemampuan diri untuk mencari cara-cara yang efektif, komprehensif dalam mengoptimalkan potensi siswa yang mampu menyentuh semua fungsi otaknya, hati, dan emosinya agar siswa-siswa mampu juga mengembangkan kemampuan dirinya sendiri sehingga terwujudnya insan kamil sesuai dengan nilai-nilai Islam. Selain itu diharapkan juga kepada guru PAI untuk memperkaya wawasannya dengan membaca buku-buku tentang potensi.

\section{DAFTAR PUSTAKA}

Agustian, Ary Ginanjar, Rahasia Sukses Membangun Potensi Emosi Dan Spiritual / ESQ, Jakarta: Arga Wijaya Persada, 2001.

,ESQ,Emotional,Spiritual

Quotient, berdasarkan 6 rukun iman dan 5 rukun Islam Jakarta:Arga, 2001.
Arikunto, Suharsimi, Prosedur Penelitian Sebagai Suatu Pendekatan Praktek, Jakarta: Renika Cipta, 2001.

Chatib, M, Quantum Teaching: Mempraktikkan Quantum Learning di Ruang Kelas, Kaifa,2010.

Departemen Agama Islam RI, Al-Qur'an dan terjemahannya, Bandung: PT. Syaamil Al-Qur'an

Hadi ,Sutrisno, MetodologiResearch, Yogyakarta: Andi Offset, 1987.

Ishak W. Talibo, Artikel Membangun PotensiSpiritual dalam Pandangan Pendidikan Islam, (ESQ Pdf.)

Kemp, Designing Effective Instruction, New York: Macmillan College Publishing Company, 1994.

Masyhud, Pengajaran Mikro untuk Mahasiswa FKIP Universitas Jember. Tidak Diterbitkan. Hand Out. Jember: UPPL dan Microteaching FKIP Universitas Jember. 2012.

Mubayidh, Makmun, Potensi dan Kesehatan Spiritual Anak, Jakarta: Pustaka AlKautsar, 2006.

Nawawi, Hadari, Penelitian Terapan, Yogyakarta: Gajah Mada Universitas Press, 1996.

Najati, Utsman, Alqur'an Dan Ilmu Jiwa, Bandung: Penerbit Pustaka, 1997 -, Belajar EQ dan SQ dari Sunah Nabi, Jakarta: Penerbit Hikmah, 1993.

--------, Psikologi dalam Alqur'an, Bandung: Pustaka Setia, 2005.

Nizar, Samsul, Pengantar Dasar Pemikiran Pendidikan Islam, Jakarta: Gaya Media Pratama, 2001.

Rusman., Model-Model ., Jakarta: PT. Raja Grafindo Persada,2012.

Sahih Bukhari Jilid IV, Kuala lumpur, 2004 
Suryanti, Model-Model Inovatif, Surabaya: Universitas Negeri Surabaya, 2008.

Widiyatmoko, Berbasis Proyek untuk Mengembangkan Alat Peraga IPA dengan Memanfaatkan Bahan Bekas Pakai,2012 (Online), (http://journal.unnes.ac.id/index.php/jpii ), diakses 10 Maret 2014. 